non-professional is appearing with increasing frequency in American mental health programs. While the use of non-professionals is hardly a discovery for most countries around the world, this kind of commonsense utilization of a hard-headed member of the patient's own neighbourhood or background class is a dramatic addition to American psychiatry. The paraprofessional or mental health technician works along with the professional in the various clinic or hospital settings and provides many of the specific direct supports that Schmideberg has mentioned as being helpful in guiding her patients back to more complete daily functioning. The paraprofessional is able to offer direct suggestion and advice, participate with the patient in problemsolving, and offer direct encouragement to him. Indeed, in the very area in which the psychotherapist is weak as a role model, the paraprofessional is strong. The paraprofessional is seen as an active participant who gets out of the office and into the real life situation along with the patient. The paraprofessional may be seen by the patient as an activist and an advocate in contrast to the office-bound psychotherapist who is passive and inhumanely non-judgmental, as Schmideberg has pointed out.

Leon D. Hankoff.

40 Montana Place,

Brooklyn, New York II 234,

U.S.A.

\section{THE SEEBOHM REPORT}

\section{DeAr SiR,}

Miss Tanner's distress at the negative reception given to the Seebohm Report by the R.M.P.A. is understandable, in a way praiseworthy, but undeniably naive (Journal, April, 1970, p. 457). Did she really expect the R.M.P.A. would acquiesce in a proposal which involved abjuration of some of its power? As a social scientist she might have been expected to know that social institutions are all resistant to change, and that psychiatry, now that it is accepted as one of component medical institutions in general, is no exception. The dominant ideology of all such institutions is always conservative (small ' $c$ ' of course), and the point is neatly demonstrated by Dr. Pilkington's last sentence in his reply-'It is to be hoped that in any future deliberations the psychiatric social workers will reconsider their position not merely by attempting to envisage a new Social Services Department but rather by studying the manner in which comprehensive and integrated psychiatric services ought to be developed in the future.' The linguistic nuances of the sequence 'merely', 'new', 'rather' carry the implication that the existing psychiatric establishment organization is basically the optimum one.

Resistance to change in social institutions is almost a universal phenomenon-witness the distrust of all forms of revisionism in political science (tragically in Czechoslovakia) as well as applied social science (tiresomely in Western democracies); for that matter, Freud was intransigently hostile to the changes in psychoanalysis proposed by Jung and Adler. Actually the protest letter by Finn, in the same issue of the Fournal, at Beccle's derogatory review of Goffman's Asylums is probably occasioned by the operation of the same forces and mechanisms. The perception of the need for change, especially if it be radical change, is experienced by some and not others. The perception may or may not depend on superior wisdom; but factors other than 'wisdom' are likely to be involved. One could perhaps hazard a guess at the age ranges and status ranges of the authors concerned. The longer one has been socialized by an institution, the more the institutional hierarchy gives one a persona and a set of roles, the more one becomes uncritically the creature of the institutionwhich is exactly one of the major ideas that Goffman is advancing, surely.

Miss Tanner had better look elsewhere for advocacy of change. The emergence of some noninstitutionalized charismatic leader is a more likely source, some one with campaigning fire and a vision, not too hampered by doubts or misgivings. This has usually been history's way. Perhaps Des Wilson could be recruited from Shelter? Changes in establishment policy are only ever won by sustained and repeated assault from without, and the reformer's lot may well be thankless, to put it mildly. It might be some encouragement to reformers to remember the case of Chadwick, who was disliked, discredited and largely destroyed for his attempts to reorganize aspects of human welfare. In July 1854 The Times jeered after his defeat 'We prefer to take our chance of cholera and the rest than be bullied into health ... The truth is Mr. Chadwick has very great powers, but it is not so easy to say what they can be applied to. Perhaps a retiring pensiph with nothing to do will be a less exceptionable mode of rewarding this gentleman than what is called an active sphere' ( $I$ ). Chadwick was thereafter sent to Victorian England's equivalent of Siberia, yet by 1889 events had vindicated him; he was rehabilitated, knighted, honoured in various ways and The Times attitude towards him is now unrecognizable. His obituary there in 1890 reads ' ... Figures and undeniable facts were the talismans with which he accomplished achievements which to the comtemporaries of his early manhood would have seemed miraculous. He may 
be said to have been 'the father of Modern Sanitary Science'. One can stretch analogy too far, but Chadwick and Seebohm are at least alike in this-that they were non-medical men and they proposed changes in paramedical aspects of social life which were unpopular. The whirligig of time may vindicate the latter as it did the former. But Miss Tanner and her extra-medicine friends will have to keep up the pressure.

\section{R. S. Ferguson.}

Department of Sociology, Government and Administration, University of Salford,

Salford 5, Lancs.

\section{REFERENCES}

(1) The quotations are from 'Edwin Chadwick, Poor Law and Public Health.' By Roger Watson, London. Longmans, Green \& Co. 1969.

\section{BOOK REVIEW HEADINGS}

DeAR Sir,

I am writing to you on a matter arising out of my review (on p. 228 of the February, 1970, Journal) of Anna Freud's Indications for Child Analysis and Other Papers: 1945-56. When I saw it in print I was astonished and annoyed to read the heading 'Anna Freudianism'. I thought, however, that no one would for a moment suppose that $I$ had invented this title.

I now discover that I was wrong, and that both Miss Freud and Mr. Masud Khan (Editor of the International Psycho-Analytical Library) did in fact assume that the title for the review was of $m y$ choosing-so no doubt many other people think the same. There is an unfortunate and totally mistaken impression that I was somehow 'getting at' Miss Freud. Anyone who reads the review with any care will see that the only adverse criticism relates to the editorial work (which I now learn was not Mr. Khan's but that of an unnamed American editor).

$22 A$ East Heath Road,

William Gillespie.

London, N.W.3.

[We confirm that the titling of reviews is carried out in the editorial office, and reviewers bear no responsibility. We are sorry that this title annoyed Dr. Gillespie; on the analogy of 'Freudian theory' and 'Freudianism', a reference to Miss Freud's distinguished work as 'Anna Freudianism' would appear to be innocuous and even complimentary. Eds.]

\section{GRAPHOLOGICAL RESEARCH IN PSYCHIATRY}

\section{Dear Sir,}

I should like to have the opportunity of collaborating with a psychiatrist or psychologist in studying the handwriting of homosexuals i.e. to get in touch with a collaborator who would be able and willing to supply an adequate source of graphologically suitable material. What is needed for that purpose is a spontaneous piece of writing in letter form, with addressed envelope and signature. Using graphology as a projective technique demands knowledge of the same basic facts as are needed by doctors, i.e. name, age, sex, status, occupation, and where first educated if not in this country. The name is important, since the graphologist needs to compare the signature with the name it is meant to represent, and work out the nature of the deviations from letter formations used in the accompanying text. However, name and signature could be dispensed with if there is an overriding need to maintain confidentiality. Needless to say, in conducting such a research, I should bind myself to observe the complete confidentiality of the material with which I was supplied.

I am aware that, if reliable results are to be expected from such a research, a blind approach will be called for. Perhaps my collaborator, if one agrees to join me, would be willing to supply handwritten letters from two series of subjects, homosexuals and controls (such as normal volunteers and nonhomosexual psychiatric patients). Every such letter could then be marked with a code number, so that my analysis of graphological characteristics would be done blind. I should be willing to fall in with any other sensible requirements to make the study a properly structured experimental enquiry.

I am interested in both male and female homosexuals. I have studied 80 handwritings of selfstyled lesbians, but have found (according to the graphological features denoting homosexuality as determined by German psychologists) only $3^{8}$ of this number to be genuine lesbians. The others were either heterosexual or bi-sexual (by my criteria). This result obviously needs following up, and that would best be done in collaboration with a therapist who knows the subjects well. To date I have obtained only $4^{0}$ handwritings of male homosexuals, so I have not been able to get very far on that side.

Possible collaborators may wish to know a little more about my own personal background. I was privately educated, and matriculated. People have always been my principal interest in life, in particular human relationships. My publications include three novels, but I later abandoned writing in favour of 